\title{
Students' Perception of English Blended-Learning in State Polytechnic of Sriwijaya
}

\author{
Munaja Rahma ${ }^{1, *}$, Zakaria ${ }^{1}$, Moehammad Ridhwan ${ }^{1}$ \\ ${ }^{I}$ English Department, State Polytechnic of Sriwijaya, Palembang, Indonesia \\ Corrresponding author. Email: Munaja.rahma@yahoo.com
}

\begin{abstract}
This study was aimed at finding out the students' perceptions of English Blended-Learning in State Polytechnic of Sriwijaya. Around 183 students from English Department, Electronica Engineering Department, Civil Engineering Department and Management of Informatics Department were taken as the writers' purposive sampling. This will expectedly give insights on how students' think about English Blended-Learning given by their lecturers. Modified Questionnaires were used to collect the data needed and they were analyzed quantitatively using the Pearson Product Moment Coefficient. Through the use of statistic descriptive analysis, the data were processed and then described in words and numbers. The result showed most of the students (> 50\%) responded that blended learning method was useful, easy to follow, give them positive attitude, and behavior to study.
\end{abstract}

Keywords: perception, blended learning

\section{INTRODUCTION}

Technology developed so fast and unpredictable. Many industries work under long distance communication by using advance technology to make their work more efficient and economist. One of technology used by industries is internet. With internet, two or more industries or two the same industries which offices are on different cities use internet to send their e-mail or having video call in doing their communication among others.

Education industry is also one of among those industries which uses internet to run its learning process. The use of internet in teaching and learning process is widely known as e-learning. The concept of e-learning changes the process of teaching and learning happened in the class from conventional one to digital one. As we know, so far, students sitting in the classroom, listening the lecture or having discussion, sometime can be nervous or even boring experience for the students. Meanwhile students need to expand their knowledge and their awareness of challenge that they will face after graduating from their college or university. So there is no another way for solving this condition is by applying anyways that make students more interest in their learning process.

State Polytechnic of Sriwijaya is one of the biggest Polytechnic in Indonesia trying to adapt its Learning Management System with this development of technology by triggering their teacher to always improve their teaching methods. State Polytechnic of Sriwijaya also gives some training and workshop related with e-learning to open and boast their teacher mind to reach institution goal, that is implementing e-learning in State Polytechnic of Sriwijaya.

Although online learning promised to improve the quality and efficiency of teaching in universities, the actual results have shown something different. Although studies, such as
[1] and [2], have demonstrated that online and classroom learning are essentially equally effective, other evidence suggests that instructors find teaching online courses to be more time consuming than teaching the same course in a traditional classroom, and some economic studies suggest that, because of their labor - intensity, online courses in an academic setting are more costly to teach than classroom courses.

Based on the writers' observation, some of the lecturers in State Polytechnic of Sriwijaya try to combine those two methods; traditional and online learning method as one of comfortable and efficient learning method to be applied to their teaching and learning. This method is known as blended learning method. Blended learning method tries to overcome monotonous that is always happen by students. Problem formulation;

- What are students' perception of English Blended learning in State Polytechnic of Sriwijaya?

- Do students like to study English by using Blended learning method?

Purpose:

- To know students' perception of English Blended learning in State Polytechnic of Sriwijaya

- To know whether or not students like to study English by using Blended learning method

Methodology:

The writer gave questionnaires to 183 students from two departments of technic students and two departments of non technic students as the representative sample of nine departments in State Polytechnic of Sriwijaya. The result of questionnaires was analyzed quantitatively using Pearson Product Moment.

Benefit:

By doing this research, the writers hope that teachers will consider blended-learning in their teaching and learning process to give impact to the students and also to adapt 
todays' globalization where anything is done online. The writers also hope, this research can give more information about students' perception related with blended learning method and also to give general reference policy on teachers' performance.

\section{LITERATURE REVIEW}

In this chapter, the following topics are discussed: 1) Online learning, 2) Traditional Learning, 3) Blended learning, 4) the definition of perception.

\subsection{Online Learning}

Online learning is a kind of learning which use internet and another technology where $80 \%$ of learning conducted online. One of the great strengths of online and mobile technologies is their potential to operate together for communicating, saving, editing or sharing information and resources, [3]. Todays' students are used to using those technologies. Even, they seem to enjoy their life without never leaving those technologies on their hands. Those potencies of technology encourage some teachers to adapt their skill with their students' habit to always use their gadget by changing their teaching method using gadget/technology too. The present education is now much different from a few decades ago due to the presence of technology that we have to accept and to benefit. The needs to have the $21_{\text {st }}$-century teachers who are capable not only to wrap all the things needed in the process of teaching and learning with the power of internet and hightech gadgets and applications but also to be respectful towards the characteristics of present students [4].

[5] says advantages of learning online

- You can learn whatever you want

You can pick the program of your dreams in traditional education, too, but that would involve traveling away from home, living in a completely unknown city, and struggling in an extremely competitive learning environment. With online education, you can take any program or course present in traditional four-year universities. For example, let's say you're mostly interested in neuroscience. All it takes is a Google search for such online course, and you'll easily find the online programs offered by some of the most prestigious universities from all around the world. You can take such a course even if you have no aspirations to apply that knowledge in your future profession, but you're simply curious to discover new interests and understand how the human brain works. The great variety of online programs and courses is a huge advantage of this type of education. It doesn't matter where you live and what you want to study - you can always find a suitable course or even a degree program that you can follow from home.

\section{- Comfort}

Forget about attending classes for hours, sitting in an uncomfortable chair, and suffering from back pain by the end of the day. You will not be bound to physical class session when you opt for online education. All lectures and needed materials are provided via online platforms, so you'll easily access them from the comfort of your home. You will not take public transport to get to campus, you won't have to spend money on gas for your car, you won't have to get up early to get dressed for class... the list of conveniences goes on and on. Comfort is a strong advantage, but it can go both ways. You mustn't allow yourself to get too comfortable when studying from home, so it would be best to abandon the couch for few hours a day and set up an inspirational studying environment in your home. All you need is a large desk and a nice, comfortable chair.

- Online courses look great on a resume.

It doesn't matter where your career stands at this moment; an online program will always look good on your resume. It will show potential employers that you're committed to learning and you're eager to obtain more knowledge and new skills. Hiring managers don't see online degrees as inferior to traditional ones. A degree is a degree. If you obtain an online degree from a prestigious university, you'll boost your career with the speed of light. You will certainly become a better candidate for a job promotion, and your resume will look much better when you apply for new positions.

\section{- Self-paced learning}

When you start browsing through interesting online courses and programs, you'll notice the Self-Paced label on most of them. What does this mean? Self-paced learning means that the students can start completing the targets at any time, and he can arrange a learning schedule that meets his individual needs. When you enroll in a traditional college program, you'll have to forget about work, hobbies, and even family. In such setting, studying has to be a priority. That's why many single parents and people who work decide to forget all about their dreams to get a higher degree.

A self-paced system enables them to make progress with rhythm that suits them. This type of system does not require attending live sessions; you can access the materials at any time that works for you. If you have to work or take care of your home and children during the day, you can study at night. That's an advantage the traditional educational system cannot beat.

- Lower costs

The fact that online programs are cheaper when compared to the ones held in a traditional campus setting is enough to convince you to consider them. The average tuition for online courses depends on multiple factors, so it varies from one program to another. If, for example, you want to enroll in the Big Data Specialization program provided by University California, San Diego through Coursera, you'll pay $\$ 399$. You also have an option to pay $\$ 49$ per course. Financial Aid is available for learners who cannot afford this fee, so that's something you should always keep in mind. We saved the best part for last: many online courses are completely free of charge. MIT, for example, offers all course materials online without any charges. Free courses 
don't usually come with certificate of completion, but they are still more than useful for anyone who wants to learn from prestigious educators.

Nevertheless, other research has indicated that learners do not recognize online learning to be necessarily beneficial due to the lack of peer-to-peer interactivity between students and instructors. Although most online units provide student access to chat and discussion forum facilities to encourage ongoing interaction, difficulty in finding time to participate and the lack of immediacy are barriers.

Unfortunately, this strategy cannot be applied in State Polytechnic of Sriwijaya where there is still a rule which guide teaching and learning in State polytechnic of Sriwijaya cannot fully conducted online. There must be face to face meeting between teacher and students in the class.

\subsection{Traditional Learning}

It is one of learning method where teacher and students having face to face meeting in the class. This teaching method usually relies on text book. Furthermore, traditional learning method usually tends to repetition and memorization.

[6] mention advantages of traditional learning

- Interactive

Most students consider the traditional classroom environment beneficial for learning because they can interact with the teacher and their classmates. Especially for people who learn better through cooperative activities and group work, the possibility of asking questions and receiving immediate answers is important. Many students prefer face-to-face interactions to technology-mediated conversations. Some students need constant reassurance that what they do is correct and that they are going in the right direction, so they need feedback to keep them moving.

\section{- Motivating}

Before college and university classes, students are used to going to school and learning in a classroom surrounded by classmates. Even if they don't need to do that anymore after high school, to combine a place traditionally meant for acquiring knowledge with the environment of their homes is confusing for them. The learning atmosphere of the traditional classroom helps them to stay focused and keeps them motivated; unlike virtual classrooms, where procrastination can become a common attitude, traditional classrooms preserve a feeling of "now and here" all through the learning process.

- Accessible

Some students don't have access to technological devices, so online classes are out of the question. Some don't know how to use them, and some don't care about them. In a traditional classroom environment, learning begins with the teacher sharing his knowledge with students, proceeds with discussions between the teacher and the students and ends with the new information written in notebooks. For students of specializations that have nothing to do with technology, printed courses and books from the library are, in most cases, enough.

- Organized

Another advantage of traditional classroom learning is that it provides students with a fixed schedule and specific periods dedicated exclusively to learning. Most adults lead busy lives these days, whether they have a demanding job or children in school. It's difficult to find time for personal study between working hours and PTA meetings, and there is always something more important to do. Students in this situation prefer to be "forced" to schedule classes first and then plan other activities around them.

\subsection{Blended Learning}

The term blended learning originated in the business world in connection with corporate training [8], then was employed in higher education [9] and lastly it appeared in language teaching and learning. It is difficult to say exactly when the term became commonplace in ELT. The term blended learning was firstly emerged in late 2003.

Each teacher who uses different kinds of teaching technique will stand on their opinion that they do the best thing in teaching their students. Some of them who uses traditional system think that most important one we can make students to be comfortable in learning in the class, the other some who use technology think that teacher will left behind when they do not use technology in their teaching and learning process.

Blended learning is the most logical and natural evolution of our learning agenda. It suggests an elegant solution to the challenges of tailoring learning and development to the needs of individuals. It represents an opportunity to integrate the innovative and technological advances offered by online learning with the interaction and participation offered in the best of traditional learning, [7]. In Australia, several universities offer online learning resources via LMS, such as Blackboard and Moodle. Content and teaching delivery is becoming more sophisticated and common as enrolment patterns change and students who have jobs require more flexibility in order to continue studying

Through blended learning method, the teachers will get more efficient time in checking the students' work, because what the teachers need to prepare is the questions and answers which is design in a very specific format. When this format of question is uploaded then the students will answer those questions in an available time set by the teacher, then, after the students submit their answer, the teacher and students will automatically will see the students score of their answers.

\subsection{The Definition of Perception}

Perception is the noun form of the verb 'perceive' which means to become aware of $(\mathrm{sb} / \mathrm{sth})$; notice, observe. 
Perception itself can be interpreted as the ability to see, hear, or understand. It can also be referred to as a way of seeing or understanding something [10]. In line with this, [11] defines perception as our recognition and interpretation of sensory information. perception also includes how we respond to the information. We can think of perception as a process where we take in sensory information from our environment and use that information in order to interact with our environment. Perception allows us to take the sensory information in and make it into something meaningful.

From the definition above it is clear that the process of learning at school or anywhere, whether it is formal or informal, will not be possible without the involvement of perception. we are not robots that move around without the capability to think because that is what differentiates us from other creatures in the world. With perception, we interact, find some problems or comfort, and make an effort to make them disappear or last. The ability to make innovation in technology or whatever it is to make human life easier or more comfortable is due to perception of human life. Perception coexists with human being and its death will very possibly put an end to human life. Suffice it to say that perception is an indispensable part of our lives.

\section{METHODOLOGY}

\subsection{Research Design}

Descriptive research design is employed in doing this research. The major purpose of descriptive research is description of the state of affairs as it exists at present. In social science and business research, researchers quite often use the term Ex post facto research for descriptive research studies. The main characteristic of this method is that the researcher has no control over the variables; he can only report what has happened or what is happening. Most ex post facto research projects are used for descriptive studies in which the researcher seeks to measure such items as, for example, frequency of shopping, preferences of people, or similar data. Ex post facto studies also include attempts by researchers to discover causes even when they cannot control the variables. The methods of research utilized in descriptive research are survey methods of all kinds, including comparative and correlational methods [12].

\subsection{Research variables}

There are four variables used in this research. They are usefulness, perceive ease of use, attitude and behavior toward blended learning method.

\subsection{Population and Samples}

The population is semester two and four students of Polytechnic of Sriwijaya from 9 departments. The writers will use purposive sampling technique where the writers take 183 students as the samples of their research from 9 departments as the representative samples of technic and non technic students who are already known by the writers that those students use blended learning method. Deliberate sampling is also known as purposive or nonprobability sampling. This sampling method involves purposive or deliberate selection of particular units of the universe for constituting a sample which represents the universe[12].

\subsection{Data Collection Techniques and Instrument}

Questionnaires are used as the instrument to obtain the data. The questionnaires were modified by the researchers themselves, and therefore, a try-out had to be conducted to ascertain their validity and reliability. The piloting students were the Management Informatics students of semester 8 who will not respond to the questionnaires. There are twenty of them involved in the questionnaires, they are presented in Bahasa Indonesia. Each item of the questionnaires has five scales with which the respondents have to respond. The scales comprised favorable statements such as strongly disagree, disagree, undecided, agree, and strongly agree.

\section{FINDINGS AND DISCUSSION}

This chapter discusses the finding and interpretations of the study. The variables involved in this study were usefulness, perceive ease of use, attitude and behavior toward blended learning method. The purpose was to know the students' perception on the implementation of blended learning.

183 students from 4 departments; electrical engineering department, civil engineering department, management informatics department and English department were involved in this study. They were in academic year $2017 / 2018$ and 2018/2019. The data from questionnaire were analyzed using Pearson Product Moment.

\subsection{Findings}

\subsubsection{Students' perception toward general knowledge of blended learning}

Among 183 students only one of them or five percent (5\%) responded that he/she didn't know what is blended learning and four of them $(22 \%)$ disagree that they knew 
what is blended learning. Meanwhile around $35.5 \%$ of them responded neutral or undecided that they know what is blended learning. However, $41 \%$ of them agreed and only $20.8 \%$ of them responded strongly agree that they know what is blended learning, as shown on table 1.

Table 1 General Knowledge of Blended Learning

\begin{tabular}{|c|c|c|c|c|c|}
\hline & & Frequency & Percent & \begin{tabular}{|c|} 
Valid \\
Percent
\end{tabular} & $\begin{array}{c}\text { Cumulative } \\
\text { Percent }\end{array}$ \\
\hline Valid & $\begin{array}{l}\text { Strongly } \\
\text { disagree }\end{array}$ & 1 & 0.5 & 0.5 & 0.5 \\
\hline & Disagree & 7 & 3.6 & 3.6 & 4.2 \\
\hline & Neutral & 48 & 26.4 & 26.4 & 30.6 \\
\hline & Agree & 86 & 46.8 & 46.8 & 77.4 \\
\hline & \begin{tabular}{|l} 
Strongly \\
agree
\end{tabular} & 41 & 22.6 & 22.6 & 100.0 \\
\hline & Total & 183 & 100.0 & 100.0 & \\
\hline
\end{tabular}

Furthermore, based on the researchers' further question given to the respondent related with whether or not many lecturers implemented blended learning in their class, 5\% percent of them or only one of them responded strongly disagree that many lecturers in their class used blended learning method and $6.6 \%$ of them disagree. Almost half of them or $44.3 \%$ responded agree that some of their lecturers implemented blended learning in their class and only $17.5 \%$ responded strongly agree.

\subsubsection{Students' perception toward the usefulness of blended learning}

Table 2 presented how students perceive about the usefulness of blended learning method. It covers the students' work quality, the effectiveness and efficiency in finishing their work, improving their honesty, improving their independence and cope their bore. Although 2\% of them responded that blended learning method is useful but $50.3 \%$ them agree that this method is useful even though only $20.2 \%$ responded strongly agree that they got the usefulness of blended learning method.

Table 2 Perception of usefulness

\begin{tabular}{|l|l|r|r|r|r|}
\hline \multicolumn{2}{|c|}{} & Frequency & Percent & $\begin{array}{c}\text { Valid } \\
\text { Percent }\end{array}$ & $\begin{array}{c}\text { Cumulative } \\
\text { Percent }\end{array}$ \\
\hline Valid & $\begin{array}{l}\text { Strongly } \\
\text { disagree }\end{array}$ & 2 & 1.1 & 1.1 & 1.1 \\
\cline { 2 - 6 } & Disagree & 5 & 2.9 & 2.9 & 4.0 \\
\cline { 2 - 6 } & Neutral & 48 & 26.2 & 26.2 & 30.2 \\
\cline { 2 - 6 } & Agree & 83 & 45.4 & 45.4 & 75.6 \\
\cline { 2 - 6 } & $\begin{array}{l}\text { Strongly } \\
\text { agree }\end{array}$ & 45 & 24.4 & 24.4 & 100.0 \\
\cline { 2 - 6 } & Total & 183 & 100.0 & 100.0 & \\
\hline
\end{tabular}

\subsubsection{Students' perception toward the ease use of blended learning}

Students responded differently in the ease use of blended learning. This variable answered whether or not easy for students to complete the task/quiz given online, easy or not for students to comprehend the topic discussed as they still have class' discussion and easy or not for them to use technology and online application.

$1.1 \%$ of the students still got difficulties with the involvement of technology in their blended learning class and $5 \%$ of them felt not easy for them to adapt with technology used in their blended learning class. Fortunately, $47 \%$ of the students felt no difficulties to comprehend the lesson and instruction given with the technology used in their blended class. Even $28.4 \%$ of them strongly agree that the involvement of technology in their blended class did not blocked them to comprehend the lesson, besides it was very easy for them to adapt with the technology/application used. Meanwhile $23 \%$ of the in the neutral position as shown on table 3 below.

Table 3 Perceive ease of use technology in blended learning class

\begin{tabular}{|l|l|r|r|r|r|}
\hline \multicolumn{2}{|c|}{} & Frequency & Percent & $\begin{array}{c}\text { Valid } \\
\text { Percent }\end{array}$ & $\begin{array}{c}\text { Cumulative } \\
\text { Percent }\end{array}$ \\
\hline \multirow{7}{*}{ Valid } & $\begin{array}{l}\text { Strongly } \\
\text { disagree }\end{array}$ & 2.0 & 1.1 & 1.1 & 1.1 \\
\cline { 2 - 6 } & Disagree & 6.0 & 3.3 & 3.3 & 4.4 \\
\cline { 2 - 6 } & Neutral & 46.0 & 25.1 & 25.1 & 29.5 \\
\cline { 2 - 6 } & Agree & 83.0 & 45.4 & 45.4 & 74.9 \\
\cline { 2 - 6 } & $\begin{array}{l}\text { Strongly } \\
\text { agree }\end{array}$ & 46.0 & 25.1 & 25.1 & 100.0 \\
\cline { 2 - 6 } & Total & 183 & 100.0 & 100.0 & \\
\hline
\end{tabular}

\subsubsection{Students' attitude toward blended learning method}

Table 4 presented how student's attitude toward blended learning method. This table shows significant value to how students' attitude in responding blended learning method. As usual there is only few students strongly disagree that blended learning method influence their positive attitude and give them comport in studying. On the other hand there $44.5 \%$ of them agree that blended learning method influence their positive attitude and give them comport in studying. More over $23.6 \%$ of them strongly agree that blended learning method influence their positive attitude and give them comport in studying. In contrast, only 2.4 percent of them disagree that blended learning method influence their positive attitude and give them comport in studying. 
Table 4 Attitude Toward Blended Learning Method

\begin{tabular}{|l|l|r|r|r|r|}
\hline \multicolumn{2}{|c|}{} & Frequency & Percent & $\begin{array}{c}\text { Valid } \\
\text { Percent }\end{array}$ & \multicolumn{2}{|c|}{$\begin{array}{c}\text { Cumulative } \\
\text { Percent }\end{array}$} \\
\hline \multirow{7}{*}{ Valid } & $\begin{array}{l}\text { Strongly } \\
\text { disagree }\end{array}$ & 2.0 & 1.1 & 1.1 & 1.0 \\
\cline { 2 - 6 } & Disagree & 4.3 & 2.4 & 2.4 & 3.3 \\
\cline { 2 - 6 } & Neutral & 52.3 & 28.6 & 28.6 & 31.9 \\
\cline { 2 - 6 } & Agree & 81.5 & 44.5 & 44.5 & 76.4 \\
\cline { 2 - 6 } & $\begin{array}{l}\text { Strongly } \\
\text { agree }\end{array}$ & 43.3 & 23.6 & 23.6 & 100.0 \\
\cline { 2 - 6 } & Total & 183 & 100.0 & 100.0 & \\
\hline
\end{tabular}

\subsubsection{Students' behavior intention to use technology on their blended learning class.}

The last variable is how students' behavioral intention to use blended learning method and everything involves in this method. It covers their another purposes (to be used to complete any task online) to interest in using blended learning, to be more active in following this method, and to be motivated in joining this method.

Based on table 5, the researcher found that $0.7 \%$ of them strongly disagree that blended learning method change their behavior and intention to be motivated and active to join blended learning class. $3 \%$ was disagree and only $34.4 \%$ of them neutral (can be motivated or not motivated). On the other hand, more and less $42.8 \%$ of them agree that blended learning method change their behavior and intention to be motivated and active to join blended learning class. Moreover 20.2\% was strongly agree that blended learning method change their behavior and intention to be motivated and active to join blended learning class.

Table 5 Behavioral intention to use technology in blended learning class

\begin{tabular}{|l|l|r|r|r|r|}
\hline \multicolumn{2}{|c|}{} & Frequency & Percent & $\begin{array}{c}\text { Valid } \\
\text { Percent }\end{array}$ & $\begin{array}{c}\text { Cumulative } \\
\text { Percent }\end{array}$ \\
\hline \multirow{7}{*}{ Valid } & $\begin{array}{l}\text { Strongly } \\
\text { disagree }\end{array}$ & 1.3 & 0.7 & 0.7 & 0.7 \\
\cline { 2 - 6 } & Disagree & 3.5 & 1.9 & 1.9 & 2.6 \\
\cline { 2 - 6 } & Neutral & 63.0 & 34.4 & 34.4 & 37.0 \\
\cline { 2 - 6 } & Agree & 78.3 & 42.8 & 42.8 & 79.8 \\
\cline { 2 - 6 } & $\begin{array}{l}\text { Strongly } \\
\text { agree }\end{array}$ & 37.0 & 20.2 & 20.2 & 100.0 \\
\cline { 2 - 6 } & Total & 183 & 100.0 & 100.0 & \\
\hline
\end{tabular}

\subsection{Interpretation}

Based the findings above, the researchers tried to interpret how the students responded blended learning method, as follow;

\subsubsection{Students' Perception toward General Knowledge of Blended Learning}

Since only $5 \%$ of the students strongly disagree and $22 \%$ of them disagree that they didn't know what is blended learning, it can be assumed that this percentage didn't give any significance number. So, we can conclude that actually they already know what is blended learning method. Moreover, based on table 2, around $46.8 \%$ was agree and $22.6 \%$ strongly agree that they know what is blended learning method. This percentage clearly explained that more than $50 \%$ of the students really know what is blended learning.

\subsubsection{Students' Perception toward the Usefulness of Blended Learning}

Based on what the researchers found through questionnaire, it strongly believed that students felt the usefulness of blended learning. It can be proved from the data got from questionnaire that $45.2 \%$ them agree that this method is useful moreover $24.4 \%$ responded strongly agree that they got the usefulness of blended learning method.

These two points refers to the usefulness that the students can get from blended learning method. These two points also can neglect the students responded to strongly disagree toward the usefulness of blended learning method since the number of students who strongly disagree was only two students or $1.1 \%$ and 5 of them were disagree.

\subsubsection{Students' Perception toward the Ease Use of Blended Learning}

The researchers found that only $1.1 \%$ of the students responded strongly disagree toward the ease use of blended learning method, and only 3.3 of them was disagree. It meant that these two points didn't give any significance number to say that almost all of them got difficulties in blended learning class. As we can see from the findings on table 3 that $45.1 \%$ agree and $25.4 \%$ strongly agree that they felt not difficult in joining blended learning class. So, we can conclude that these two points direct us to conclude that most of students felt easy in joining blended learning class including to adapt with any technology/application used in this method.

\subsubsection{Students' Attitude toward Blended Learning Method}

Students interest on what they study usually will influence their attitude. Based on the finding above related to students' attitude toward blended learning method, it can be seen from the table (table 4 ) that $1.1 \%$ and $2.4 \%$ were strongly disagree and disagree that blended learning help 
them to open their mind to new knowledge or method used in the globalization era. Nevertheless, $44.5 \%$ and $23.6 \%$ agree and strongly agree that blended learning help them to open their mind to new knowledge or method used in the globalization era. This finding gave us sense that blended learning can help students to know new knowledge and adapt themselves to new method that will be used or even already used in their life experience. It is in line with the research done by [13], it is stated that students' initial concerns about both the medium and their ability to do the task appeared to be effectively countered by their experiences.

\subsubsection{Students' Behavior Intention to Use Technology on Their Blended Learning Method}

$42.8 \%$ of the respondents were agree that blended learning motivated them to encourage their interest to find another benefit of using blended learning (to be used to complete any task online), made them to be more active in following this method, and to be motivated in joining this method. The Irish students felt that the use of technologies in higher education could beneficially transform learning and make a positive difference to studying; however, the students also insisted that technologies would never replace their lecturers. The students indicated that technologies have to be properly integrated with an approach to teaching, not just be used for the sake of technology, [13]. This finding was also supported by 20.2 $\%$ of the respondent who responded strongly agree to these variables. And of course it gave us much sense that blended learning motivated the students to have intention to use technology on their blended learning class.

\section{CONCLUSION}

One of the purpose doing this research is to know students' perception toward English Blended Learning. This purpose was answered through questionnaires given to 183 respondents. The conclusions can be drawn, first, most of the students (more than $50 \%$ of the respondents) knew what is blended learning. The result showed $46.8 \%$ of respondents agree and $22.6 \%$ strongly agree that they knew what is blended learning.

Second, $45.2 \%$ of the respondents signed agree that this method was useful moreover $24.4 \%$ responded strongly agree. Third, most of the respondents $(45.1 \%)$ agreed and $25.4 \%$ was strongly agree that they felt not difficult in joining blended learning class

Fourth, $44.5 \%$ and $23.6 \%$ agreed and strongly agreed that blended learning help them to open their mind to new knowledge or method used in the globalization era.

Fifth, $42.8 \%$ of the respondents agreed and $20.8 \%$ strongly agreed that blended learning motivated them to encourage their interest to find another benefit of using blended learning.

\section{ACKNOWLEDGMENT}

This research was done under contract number 5512/PL6.2.1/LT/2019 on 18 July 2019.

\section{REFERENCES}

[1] Anderson, T. The Theory and Practice of Online Learning: Second Edition. Edmonton: AU Press, Athabasca University. 2008.

[2] Beynon, M. 2007. Computing Technology for Learning - in need of a radical new conception. Educational Technology \& Society 10 (1), 94 106. 2007.

[3] Creanor, J. M. Learning with Online and Mobile Technologies. Great Britain: Gower Publishing Limited. 2010.

[4] Price, C. 2012. Why don't my students think I'm groovy?: The new "r"s for engaging millennial learners. (Online), retrieved 20 October 2016 from http://www.drtomlifvendahl.com.

[5] Norman Stepanie 2016. 5 Advantages of Online Learning: Education without Leaving Home. (Online), retrived 15 April 2019 from https://elearningindustry.com/5-advantages-ofonline-learning-education-without-leaving-home.

[6] Paduraru Carmen (2019). The Advantages of Classroom Learning. (Online) retrived 15 April 2019.

https://classroom.synonym.com/advantagestraditional-classroom-learning-7964781.html

[7] Thorne, K. 2003. Blended Learning: How to Integrate Online and Traditional Learning. Great Britain: St Ives plc.

[8] Sharma and Barrett, 2007. Blended Learning: using technology in and beyond the language classroom. Oxford: Macmillan.

[ 9] MacDonald, J 2006 Blended Learning and Online Tutoring. Aldershot, Hampshire: Gower.

[10]Hornby. 1989. Oxford Advanced Learner's Dictionary, Fourth Edition. Oxford: Oxford University Press.

[11] Study.com. 2018. What is Perception and why is it important? Retrieved from https://study.com/academy/lesson/what-is- 
perception-in-psychology-definition-theoryquiz.html.

[12]Kothari. 2004. Research Methodology: methods and techniques, Second Revised edition. New Delhi: New age International, Limited Publisher

[13]Moyley, K \& Wijngaards, G 2012 Students reaction to learning with technologies. United State: IGI Global. 